\title{
Australian Involvement in the Malayan Emergency
}

\author{
József ONDRÉK ${ }^{1}$
}

\begin{abstract}
Australian defence and foreign policy experienced a great shift in 1942. From that year on, the nation began to think of itself as an independent entity, and a key player in Southeast Asia. The first armed conflict that Australian units participated in after the end of the Second World War was the Malayan Emergency, where all service branches contributed forces to the successful counterinsurgency war. The aim of this article is, firstly to look at the events and factors that initiated this shift in Australian policy, and secondly to analyse the forces the nation committed to fighting the Emergency. This analysis includes the fighting forces of the Royal Australian Air Force, the Army as well as the Navy.
\end{abstract}

Keywords: Malaya, Emergency, Australia, policy, defence, operation, Cold War, Southeast Asia

\section{Introduction}

Australia's relationship with Southeast Asia has always been a very interesting and at the same time a significant one. During the age of colonization, this region served as a spring board to reach that great uninhabited southern land, as the explorers of that time saw it. Later, following the First Fleet, and the complete colonization of Southeast Asia, the relationship turned to be an even closer and complex one. On the one hand, Australia had good bilateral trade relationship with this resource-rich region; while on the other hand, it also regarded the dominions of the British Empire as a defence guarantee for its own self-defence. Since the kings and queens in London were half a world apart, it was Malaya and Singapore, which acted as a forward military base, upholder of British interests in this part of the globe, and finally as a warrant reassuring Australia of defence from outside aggression. As industrialization became a major economic factor Down Under too, the ties became even closer, since Malaya's cheap tin and rubber was vital to Australia's economy.

This close and mutually beneficial relationship was severed by the outbreak of the Second World War. The fall of both Malaya and Singapore-along with the fall of the Dutch East Indies - significantly weakened European presence in the region. This created an entirely new security environment for Australia, something that the only 41 years old nation at the time had to cope with. The aim of this essay is to analyse one instance of post-World War II (WWII) measure of how Australia as a nation tried to face this new security situation in the second half of the twentieth century. Australia's role in the defence of Western interests in Southeast Asia grew remarkably in this period and the country's participation in many armed conflicts - especially the Malayan Emergency and the Vietnam War-further underlines this. Australian participation in the Malayan Emergency is thus significant for various reasons.

International Officer, National University of Public Service, International Relations Office; e-mail: jozsef. ondrek.89@gmail.com; ORCID ID: 0000-0002-1831-5479 
Firstly, it was the first major overseas commitment after WWII. Secondly, it was the first time that Australia had to fight a limited counterinsurgency (COIN) war against politically inspired revolutionary forces, and finally, because in many ways, the events of Malaya paved the way for the Vietnam War.

It is also important to mention that the conduct of the Malayan Emergency is considered by many COIN experts a successful model of how to fight a war that in addition of achieving military victory has to "win the hearts and minds of the population." Australia committed a relatively small force to the fight but gained invaluable expertise in jungle and COIN warfare as well; this makes the analysis of the country's involvement in the Malayan Emergency interesting in the light of recent world events. The analysis of the events and forces in this essay also supports the latest requirements of military science research, which finds it essential to process and incorporate the lessons of military history into both officer training and education. [1]

\section{Australian Defence Policy in the 1950's}

Australian foreign policy experienced a major shift during WWII. As mentioned earlier, the fall of both Malaya and Singapore-and as far as security assets were concerned the loss of His Majesty's Ships Prince of Wales and Repulse - eradicated the sense of security and British protection that the country enjoyed until "Japan's bombings of Darwin and Broome in 1942 brought home the vulnerability of white Australia and challenged the legitimacy of British rule over [...] Australasia.” [2: 154] This wakeup call ushered Australia into a new foreign policy agenda, which symbolically started with the Statute of Westminster Adoption Act in 1942, when the Australian Parliament formally adopted the Statute of Westminster from 1931. The Statute gave the dominions right to act independently of the British Parliament, and the adoption of it signified a change in Australian foreign policy from focusing on the United Kingdom to the United States. This was indeed a significant and unexpected change, since when Prime Minister John Curtin's Labor Government took office on the $7^{\text {th }}$ of October 1941, the new Minister for Foreign Affairs dr. Herbert Vere Evatt's first speech in Parliament had emphasized that there would be no vital change in Australia's foreign policy. [3: 39] In a few months' time, external events changed the course of Australian foreign policy decidedly.

The end of WWII altered the strategic situation once again. Outside factors, such as the new Cold War divide, the First Indochina War and especially the Chinese Civil War were seen as security liabilities in Southeast Asia. The outbreak of the First Indochina War in 1945 — whose leaders Ho Chi Minh and General Vo Nguyen Giap applied the Maoist theory of revolutionary warfare for national liberation perfectly-already caused grave concerns as far as Western foreign policy objectives were concerned. However, it was the fall of China to Communism after the long and bloody civil war that served as a trigger point for the creation of Asiatic defence organizations. Furthermore, the role Australia began to plan for itself after WWII showed that "the pre-war isolationist thinking [...] had all but disappeared. A new era of post-war Labour Party idealism, and concern for Australia’s future security, shaped immediate post war foreign policy.” [3: 41]

The 1949 Federal election in the country changed many things, the Labor Government was replaced_for a long time to come-by a conservative government lead by Robert 
Gordon Menzies, but the main foreign policy objectives remained the same. The notion at the time was that "the United States and Great Britain, had not formulated precise policies for the Asian area. [...] Therefore, a greater burden of responsibility for security in the South East Asian area, would rest with Australia.” [3: 41] Under such circumstances, it is clear to see, why the country abandoned its isolationist policies and actively sought membership in defence organizations.

The first of such organizations in the region was ANZAM, which stands for Australia, New Zealand and Malaya in 1948. The threat to sea lines of communication in Southeast Asia (SEA) was the main reason behind the creation of the agreement, but "ANZAM itself was not a treaty but rather an agreement between participating naval forces on certain higher command functions necessary for the protection of maritime trade.” [4] As of 1948, most of Malaya, with the exception of the colonial territories of Malacca and Penang, was under British protectorate, thus it was essentially still a multilateral agreement involving Britain. [5: LXIII] In a way, it was a case of old habits die hard for the Australian and New Zealand Army Corps (ANZAC) countries, since the agreements included British interests, but "Australia's commitment to ANZAM brought with it a sharpened sense of place in Southeast Asia and a policy of concentrating defence efforts in its neighbourhood.” [6: 46]

ANZAM had two other important influences on the Royal Australian Navy (RAN). Firstly, on a strategic level, it designated anti-submarine warfare as the role of the RAN, something that was to shape and influence it for decades to come. [7: 28] Secondly, it initiated a highlevel discussion between the RAN (on behalf of the ANZAM nations) and the United States Navy (USN). This liaison resulted in the Radford-Collins Agreement, which is a working level practical arrangement between the USN and ANZAM that also "predates the ANZUS (Australia, New Zealand, United States Security Treaty-author) agreement by about six months”. [8] It is also interesting to note, that this agreement is still valid today, despite of all the geopolitical changes in the regions it covers, or the termination of ANZAM.

In the same year, the creation of NATO paved the way for more formal and inclusive defence treaties. In the SEA region, this culminated into the signing of the ANZUS treaty in 1951. In it, "the three signatories pledged to 'maintain and develop their individual and collective capacity to resist attack'.” [9] It is interesting to note, that in this early 1950's security situation, the United States' policy was still more anti-colonial than what it would become only 3 years later. For this reason, Britain was not invited to join the ANZUS treaty. Firstly, inviting Britain would have opened the door to other European states with colonies still in Asia (that is mainly France fighting in Indochina). Secondly, in 1951 the British were very much bogged down in the Malayan Insurgency and the United States did not want to get involved in that conflict at all.

While the ANZUS treaty was not expanded to include Britain, another treaty was created which allowed it to contribute more to the joint security of the SEA region. By the mid1950's, defence cooperation creation was in full swing around the world. In a year's time the Bagdad Pact (also referred to as METO) was created in Bagdad, and as a response to NATO the Warsaw Pact was signed in Warsaw including all Eastern Block European countries from Albania to the USSR. [10] The deteriorating security situation in SEA also called for a defence treaty, so "The South East Asia Treaty Organization (SEATO), formed in 1954 tried to do for Asia what NATO did for Europe.” [11] Australia was one of the founding countries and SEATO played the major role in the country's foreign and defence policy until 
the termination of the organization in 1977. After the creation of SEATO, Australia (and New Zealand, as well) took up larger responsibilities in the region, but it also has to be stated, that right from the beginning SEATO had many problems and limitations. These ultimately caused the demise of the organization, and in case of the defence of Malaya, it was not considered sufficient enough. For example, in a minutes entitled Trends of Events in SE Asia and dated the $14^{\text {th }}$ of November 1954, Anthony Head, Secretary of State for War of the United Kingdom writes to UK Prime Minister Anthony Eden urging the swift creation of "a joint Australian, New Zealand, American and British planning organisation which can consider the whole situation and make proposals for stiffening up the defence of Malaya against subversion etc., in a cold war." [5: 80] The ink had barely dried on the SEATO agreement — signed on the $8^{\text {th }}$ of September-yet one of the founding nation's Secretary of War already thought of a new organization to sufficiently deal with the Malayan situation. In a way, this notion can be considered behind the establishment of the Far East Strategic Reserve (FESR—also referred to as Commonwealth Far East Strategic Reserve) in 1955.

The creation of SEATO also coincided with the formulation of the so called Domino Theory by US Secretary of State John Foster Dulles. This theory significantly influenced Australian policy towards SEA for many decades. As far as the Malayan Emergency was concerned, however, it did not play such a major role, since Royal Australian Air Force (RAAF) units were already engaged in Malaya starting from 1950. On the other hand, it has to be mentioned that regular Australian Army units only entered the fray in Malaya after 1954 as part of a SEATO commitment. Thus, at least in a way, the Domino Theory not only lead Australia into the Vietnam War in the 1960's, but it also made the nation commit ground troops in Malaya.

With the signing of the formal ANZUS and SEATO treaties, it is clear to see how Australia's defence policy really shifted from Britain to the United States in the post-WWII era. They looked for protection from Uncle Sam rather than Her Majesty. This agenda later stayed as a major influence on Australian foreign policy, when the country joined American lead wars on terrorism, and it is still relevant nowadays.

\section{The Outbreak of the Malayan Emergency}

Before detailing the actual Australian units fighting the Communist insurgents in the Malayan jungles, one has to briefly mention the outbreak of hostilities, and why the actual conflict occurred in the first place. The social and economic background to the outbreak of the Emergency is a very complex matter to analyse that has filled numerous books. In many ways, the Malayan situation was very much like the Indochinese one at the time. Both territories had a Communist Party dating back to the late 1920's, a poor and dissatisfied population, Western colonizers, and charismatic leaders, in the person of Chin Peng in Malaya. Similarly to Ho Chi Minh in Indochina, who worked for the Allies against the Japanese in WWII, Chin Peng fought with British support in the Malayan People's Anti-Japanese Army (MPAJA).

The end of WWII in SEA signalled a certain change. Although Japan was bombed into capitulation by atomic and conventional bombs, most of the Japanese occupying forces in SEA stood undefeated. There were no victorious Europeans defeating them in the eyes 
of the local nations, and this, coupled with the embarrassing defeats the European powersmostly Britain and France-suffered at the beginning of the war changed the psyche of many Asian nations and the myth of European invincibility was lost. In case of the MPAJA, just like in case of the Vietminh, it was also important that their fighters had lived in the jungle for years and gained invaluable experiences in both small unit and guerrilla warfare against the Japanese. Following the end of the war, the MPAJA laid down most of its arms in December 1945, but significant number of weapons, ammunition and other supplies captured from the Japanese were hidden away in their base camps deep in the jungle. [12: 35-36]

Transition from guerrilla warfare to a peaceful political party was really daunting to most Malayan Communist Party (MCP) members and former MPAJA veterans. The smooth transition was further hindered when it was revealed that Loi Tak, the leader of MCP at the time, was in fact a double-or even a triple-agent, and the British Special Branch infiltrated the party leadership with him. [12: 38-41] After such a blow, the young Chin Peng, a distinguished fighter who received the Order of the British Empire for his role in the WWII took over the party leadership. Although he tried reforms, contacting international and neighbouring communists and raising support for Malayan independence, his toil produced only mixed results, and by the middle of 1947, the MCP leadership was leaning towards advocating violence in order to achieve their political aims. For this purpose, the Malayan Races Liberation Army (MRLA) was created as a military wing of the MCP. [12: 60] Reforms were tried by the British in Malaya with mixed results and following the murder of three European planters and their Chinese assistants on the $16^{\text {th }}$ of June 1948, Edward GentGovernor of the Malayan Union since 1946-declared a Federation-wide Emergency on the $18^{\text {th }}$ of June 1948 . The twelve-year-long armed struggle had begun that would officially last until 1960.

It is rather unique to Malaya that this aforementioned armed struggle was called an Emergency. High Commissioner Gent declared a state of emergency, not only because of the attacks on British interests, but because of British interests themselves. It was for insurance purposes that the whole war was officially referred to as emergency, and "the enemy as Terrorists, Communist Terrorists, or CTs. Most insurance policies would cover losses due to terrorism but had a clause precluding payments for damage caused by war.” [13: 83] Thus it is clear to see and important to note, that the CTs themselves were not terrorists but insurgents. While there are some similarities between terrorist and insurgent warfare, they are still significantly different. [14] Although the confusing nomenclature by the British administration does not help the situation, efforts of the MRLA could not be considered terrorist in the modern sense of the word.

\section{Australian Armed Forces in the Malayan Emergency}

After the short analysis of the general political and strategic situation of the post-WWII world of SEA, the focus may now be turned to the actual Australian involvement in the conduct of military operations during the Malayan Emergency. For the sake of clarity, it is best to take a closer look at the Australian involvement in Malaya in a way that is divided into service branches. The Royal Australian Air Force, the Royal Australian Navy, and the Royal Australian Army, in the form of Royal Australian Regiments all contributed to the fight. 


\section{Australian Aerial Operations in Malaya}

"The main characteristic of air forces in Malaya during the Emergency was the variety of its component parts.” [15: 31] The air forces of three countries, the United Kingdom, Australia and New Zealand participated and they all used their own assets. It was also characteristic of the Emergency, that-due to its length and the technological advancements made in the 1950's - the variety of obsolete types were later gradually replaced by more modern ones, when the squadrons were re-equipped, and this was the case with the RAAF, too.

The first Australian force to arrive in Malaya were the contingent of the RAAF on the $19^{\text {th }}$ of June 1950. These were the Douglas DC-3 Dakota transport aircraft of the No. 38 Squadron (Sqn.) from Richmond, New South Wales, which arrived at Changi, on Singapore Island, as part of the RAAF response to the Malayan Emergency. [16: 152] Due to the postWWII downsizing of armed forces all over the world, the number of airbases on the Malayan Peninsula were limited, too. The main airbases of the Royal Air Force-the ones that RAAF assets used too-were RAF Tengah, Seletar, Changi, and Sembawang, which also served as a Royal Naval Air Station (RNAS). All of these were located on Singapore Island, while RAF Kuala Lumpur was in the state of Selangor, on the western side of the Malayan Peninsula, and RAF Butterworth was located in the state of Perak, on the north-western part of the peninsula, close to the Thai border. These were the airbases that could accommodate larger transport and bomber aircraft, as well as jet fighter-bombers. As the Emergency went on, a large number of smaller, auxiliary airfields and landing strips, as well as helicopter landing zones were created, but RAAF aircraft did not use these, due to the types Australians used, which were not suitable for such airfields. All of the RAAF units were officially integrated into the British Far East Air Force (FEAF), but they were part of the No. 9 (Composite) Wing, as to avoid individual squadrons being placed under British command. [16: 153]

As far as the types of missions were concerned, RAAF squadrons were engaged in offensive air support, immediate air support-or as it is also called: close air supportmedium range transport and last but not least, psychological warfare operations.

For medium range transport mission, the RAAF used the aforementioned Douglas Dakotas of the No. 38 Sqn. only. These WWII-vintage aircraft stayed in Malaya until December of 1952. When they were finally withdrawn, they had flown 1829 tons of supplies, airdropped 805 tons and carried over 17,000 passengers. [16: 153] Furthermore, they showed a serviceability of $84 \%$ in 1951-1952, which is a testament of not only the reliability of the venerable old Dakotas, but also to the professionalism of the Australian ground personnel, who had to keep them flying in less than ideal climate. [15: 77]

The air transport need of the operations obviously were not covered by RAAF assets solely, and the RAF operated three dedicated transport squadrons while the Royal New Zealand Air Force (RNZAF) also contributed a flight of Dakotas from their No. 41 Sqn. It is interesting to note that, owning to the re-equipment with new aircraft, the medium range transport capabilities of the fighting forces got depleted by the end of 1951. No. 21 (RNZAF) squadron was withdrawn to New Zealand to re-equip with Bristol Freighter aircraft, and the RAF squadrons were experiencing serviceability issues with their new Vickers Valetta C.1-s, thus the Australian Dakotas, with their excellent serviceability rate, had to compensate for this reduced capability. [15: 76] 
Transport capabilities were in huge demand also because supply droppings were essential for the platoons on jungle patrol. "Drops to individual platoons are [were] quite normal and are [were] carried out with clockwork regularity and precision”, writes Brigadier Francis H. Brooke in 1954, who served in Malaya, and would later become the first General Officer Commanding the Malayan Federation Army. [17: 16] Also adding that the "whole process is [was] so good that the infantryman tends [tended] to take it for granted. Indeed, the complete dependence on air supply is [was] the finest, if silent, tribute to the Air Forces.” [17: 16]

For offensive and immediate air support, altogether 4 RAAF squadrons served in Malaya. These were No. 1, No. 2, No. 3 and No. 77 squadrons, but regarding the lengths of the deployment and the actual tonnage of bombs dropped, No. 1 stands out from the rest of them. The No. 1 Squadron of the RAAF joined Operation Firedog, the Royal Air Force (RAF) campaign against Malayan communist insurgents in July 1950, a few weeks after the Dakota squadron. [18: 83] It was one of the three RAAF units equipped with the Avro Lincoln, a heavy, four piston-engine bombers developed in 1944 from the Avro Lancaster used extensively during WWII. Its categorization from heavy was changed to medium after 1945, but nevertheless this was the largest bomber at disposal at the time for both the RAF and the RAAF. It could carry 6,800 kilograms of bombs, and in the low threat aerial environment of Malaya, where there was no enemy air force to encounter, and no real anti-aircraft-artillery, their age and lack of speed did not matter. The RAAF Lincolns were loved by their crews, and they had by far the highest serviceability rate of any of the attack aircraft, "in excess of 70 per cent-considerably higher than that of their Canberra replacements.” [15: 31]

In the course of their operation, they were employed in level bombing as a harassment of insurgents in the jungle, usually with standard $500 \mathrm{lb}$ and $1000 \mathrm{lb}$ bombs. However, " 4000 lb block-buster bombs were also dropped by the Aussie Lincolns, the idea being that one such bomb should clear an area in the jungle enough for a helicopter to land.” [18: 83] This practice, like many other experiences of Malaya, was later taken over by Americans in the course of the Vietnam War. Target marking, in a very similar way to that of the Vietnam War a decade later, was also employed in Malaya. Crews experimented with several types of target markings, "but the most successful for day ops proved to be smoke flares dropped by low-flying Austers [Taylorcraft Auster observation aircraft—author], a highly specialized task carried out by pilots operating under the most difficult conditions.” [18: 83] These could be considered forerunners of the Forward Air Controllers (FACs) of the Vietnam War, as the theory was the same behind the action. As far as the actual bombing technique was concerned, it was also conventional, with aircraft flying in vic formation, dropping their load of $10 \times 1000 \mathrm{lb}$ general purpose bombs at one second intervals, or sometimes simultaneously. [18: 84] However, operations in Malaya certainly could not be considered a piece of cake for the aircrews, as they had to maintain close formation flying for up to four hours, missions were flown day and night, in tropical weather and scorching heat.

Due to the terrain there were triple canopy jungles where the target could not be seen, therefore this level area bombing operations could seem like a waste of resources, but the results showed differently. According to captured insurgents, the harassment of the Lincolns, and that of the air forces in general, it was really effective, and even Chin Peng, the head of the MCP almost lost his life because of one such raid in 1953. [19: 51] Indeed, during the conflict, the value of offensive area bombing operations was demonstrated frequently. For example, in Operation Kingly Pile on the $21^{\text {st }}$ of February 1956, which was 
a joint strike at a CT (Communist Terrorist, as the British called the insurgents) camp in the State of Johore, RAAF Lincoln and RAF Canberra bombers completely destroyed the camp of the $7^{\text {th }}$ Independent Platoon of the MRLA, killing 22 insurgents, including Goh Peng Tuan, their commander. [20: 76] In their first year alone, RAAF Lincolns of No. 1 Sqn. dropped around 2,500 tons of bombs, both by day and night operations, in flying 744 sorties and 3,303 operational hours in all weather. [18: 85] In the almost 8 years of continuous operation, the RAAF Lincolns dropped almost 17,500 tons of bombs, which amounts to 85\% of the total tonnage dropped by all aircraft in Operation Firedog. [18: 87]

Along with conventional bomb dropping, the Lincolns also participated in training, leaflet dropping psychological warfare operations and SEATO exercises. Thanks to the low threat environment, the good reliability and the level bombing conduct of operations, only two Lincolns were lost during their deployment, and none of those due to enemy action. [16: 153] Although, with the arrival of the Lincolns after the Dakotas, RAAF aircraft were part of the No. 90 (Composite) Wing as a parent unit, air operations came under the overall control of the Commander-in-Chief of the Far East Air Force (of the RAF, previously called Air Command Far East), while the actual operational control was exercised by the Air Officer Commanding Malaya, who was in turn subordinate of the High Commissioner. [20: 65]

The offensive air support role of No. 1 Sqn. was taken over by No. 2 Sqn. of the RAAF in June 1958. This opened a new chapter in the logbook of the RAAF, as the Canberras were jet powered, and the first bombing sortie flown on 3 September 1958 marked the first jet bomber mission ever for the RAAF. [16: 154] However, the Emergency was winding down by that time, the Briggs Plan worked in winning the hearts and minds of the population under the implementation of Sir Gerald Templer, High Commissioner of Malaya between 1952 and 1954, and the insurgents were pushed to the Thai border areas. Thus, the Canberras only saw limited action compared to their forerunners, the Lincolns. [15: 47] They flew the last bombing sortie in Malaya in January 1959, but No. 2 Sqn. could not have known that in the following decade, they were to see intense action again in SEA, at that time aspart of the Australian forces fighting alongside the United States in the Vietnam War. The squadron stayed at Butterworth airbase even after the end of the Emergency, as part of the Strategic Reserve forces until early 1967, when they redeployed to Phan Rang in South Vietnam. [20: 78]

Compared to the reliable Lincolns, the high-tech jet Canberras also had a much lower serviceability rate due to their complexity. As far as jet bombing techniques were concerned, the Canberras flew both day and night missions, but the close vic formation of the Lincolns was changed to line astern flying, with larger gaps among the aircraft during the night. [15: 59]

The other two RAAF squadrons for offensive operation were No. 3 and No. 77 both flying the Commonwealth Aircraft Corporation (CAC) Sabre jet-fighter, an Australian license built and modified version of the North American F-86 Sabre, used to great effect in the Korean War by the United States Air Force. They were deployed to Malaya, RAF Butterworth together with the Canberras, and due to the Emergency winding down, they, too, saw little action. No. 3 deployed there on the $1^{\text {st }}$ of July 1958, while No. 77 arrived as late as 1 February 1959. [15: 47-48] They still managed to fly some sorties though, the first taking place on 13 August 1959. [16: 154] Along with the Canberras, both Sabre units were part of Australia's SEATO contribution too, and they were also part of the Commonwealth Far East Strategic Reserve (commonly referred to as the Far East Strategic Reserve [FESR]). Their role in FESR would be more significant later, as Australian Sabres provided protection 
for Malaya during the Konfrontasi with Indonesia a few years later. The CAC Sabres also found their way into the hands of the newly created Royal Malaysian Air Force as a gift between 1969 and 1972. [21] Under the umbrella of FESR, Australian squadrons were regularly based at Butterworth airbase until the disbandment of the RAAF's No. 79 in 1988.

Next to offensive and transport operations, RAAF air assets also took part in psychological warfare operations in Malaya. However, most of these operations, which included leaflet dropping and broadcasting messages via loudspeakers on low flying aircraft, were conducted by the RAF. Occasionally, RAAF Dakotas and Lincolns also dropped leaflets, most notably on 3 August 1950, when No. 38 Sqn. Dakotas, along with other RAF aircraft, dropped 103,000 leaflets over Communist held territories. [22: 30] The Dakotas also occasionally served performing the role of casualty evacuation and weather reconnaissance, but these roles were mostly fulfilled by RAF aircraft, just like all the other roles of air operations in Malaya not mentioned here in an Australian context. These include helicopter assault, search and rescue (SAR), maritime reconnaissance, strategic reconnaissance etc. missions that were all the responsibility of the RAF and not the RAAF.

\section{Australian Ground Operations in Malaya}

Combat operations for Australian ground units started only in a relative late stage of the Emergency. Australian soldiers had been involved in the training of British soldiers in jungle warfare, even before Royal Australian Regiment troops set foot on Malayan soil. In fact, by 1952, when the Brigg's Plan was starting to show its results under the direction of Sir Gerard Templer, at least part of the success was "attributable to the excellent training they [the British soldiers-author] received at the Far East Land Forces School of Jungle Warfare in Johore, where most of the instructors were tough and experienced Australians, who had fought in New Guinea.” [20: 45]

As the SEATO talks were going on in the background, and ANZUS did not include the UK, Britain tried to strengthen its relationship with Australia and New Zealand again. Sir John Harding, Chief of the Imperial General Staff was sent by the Churchill Government to discuss defence issues in SEA, and in October 1953, "Harding informed Australia and New Zealand of Britain's intention to strengthen the ANZAM agreement, and to form a Far Eastern strategic reserve for the defence of Malaya.” [23: 3] This process continued at the Commonwealth Prime Ministers Conference in 1955, and on 1 April 1955 Prime Minister Menzies announced that Australia was going to participate in the Commonwealth Strategic Reserve, which was "established for the defence of Malaya, and is also available for use in operations against the Communist terrorists.” [24: 233]

As a result of this commitment, one battalion of the Royal Australian Regiment (RAR), and a battery of Australian artillery was deployed at a time, on a rotational service. The $1^{\text {st }}, 2^{\text {nd }}$ and $3^{\text {rd }}$ Battalion of RARs all served in Malaya. They were all part of the $28^{\text {th }}$ Commonwealth Infantry brigade together with British units, and a New Zealand engineering squadron. [20: 54] The foremost RAR to arrive in Malaya was the $2^{\text {nd }}$, together with the $105^{\text {th }}$ Medium Battery of the Royal Australian Army (RAA) in September 1955, but 2 RAR ( $2^{\text {nd }}$ Battalion, Royal Australian Regiment) did not start operations until the $1^{\text {st }}$ of January 1956. [25: 222] They were nominally stationed at Minden Barracks, in the State 
of Penang, but it was rare that they were there to be found, as most of the time they were engaged in operations. [22: 11]

The Australian contribution in the Malayan Emergency also illustrates how big a role the country took in SEA affairs, something that lead to Australia's involvement in the Vietnam War, as well. Every RAR in Malaya was given an area of operations with an allotted target. These were one or more organized groups of CTs. The CTs had a known area of operation, and these were the determining factors in the establishment of operation boundaries. [26: 25] The first action for 2 RAR was Operation Deuce, a search and security operation in the state of Kedah, at the Thai border of the peninsula. The operation ended on the $30^{\text {th }}$ of April, when 2 RAR handed over the responsibility of the area to the $1^{\text {st }}$ battalion of the Royal Malay Regiment. [22: 11]

The next operation 2 RAR participated in was Shark North, starting from early May in the State of Perak. In the end, this turned out to be the most intense operation Australian forces participated in during the entire Emergency. On the $22^{\text {nd }}$ of June, a patrol was ambushed by CTs, the firefight drew other Australian units into the fight as well, but the communists managed to escape into the jungle, leaving 3 dead and 3 wounded Australians behind. [22: 11-12] 2 RAR suffered further 2 casualties almost a year after the first occasion on the $24^{\text {th }}$ of June 1957. This time, they discovered a large communist camp, and in the subsequent firefight with its inhabitants, suffered two killed and one wounded. [22: 11-12] This amounts to five killed in action in one year for 2 RAR, which is $38 \%$ of all casualties suffered by the Royal Australian Army during the Emergency. [27] 2 RAR was withdrawn from operations in August that year and left Malaya in October.

The previous unit of Australians was replaced by 3 RAR from September 1957, although they only started operating after a training period on the $1^{\text {st }}$ of December 1957. [22: 12] Just like the first unit, they too were supported by an artillery battery on a deployment. This time it was the $100^{\text {th }}$ Field Battery, also called the "A" Battery of the RAA. [25: 222] 3 RAR was based at Minden Barracks as well, and their first operation was Shark North, a search and security mission, the one that 2 RAR took part in previously. 1958 opened with Operation Ginger for 3 RAR, which covered an estimated area of 3,100 square kilometres in Perak, and they were in search of 170 elusive CTs in the jungle. In the end, the battalion pursued the CTs on until they crossed the Thai border, where they could no longer follow them. When it was finished, Operation Ginger was considered a success, as the State of Perak was declared a safe area in 1959. [25: 222] 3 RAR departed from Malaya to Australia in October 1959.

The place of 3 RAR was taken over by 1 RAR on Malayan soil. The unit previously fought in Korea, which they left in March 1956. They had also received jungle warfare training at Kota Tinggi, before starting combat operation on the Malayan Peninsula. [28] Their supporting battery was the 101 Field Battery of the RAA. [25: 222] 1 RAR's first mission, Operation Bamboo took them to North Perak, near the Malayan-Thai border, basically where the previous unit left off. [20: 62-63] "During the next two years the battalion was on patrol on the Malaya/Thai border spending weeks at a time searching and laying ambushes.” [28] Their activities included participation on Operations Magnet and Jackforce in the same area as before, right until Malayan Prime Minister Tunku Abdul Rahman declared the Emergency to be over on 31 July 1960. However, 1 RAR's deployment did not end then, since they were deployed as part of the FESR, and stayed in Malaya until 29 October 1961. [22: 11] 
Altogether, the Australian Army suffered 13 killed, 24 wounded in action. Together with the losses of the RAAF, Australia lost 15 men, and a further 27 were wounded in operations. [27]

\section{Australian Naval Operation in Malaya}

The Royal Australian Navy's (RAN) operation in Malayan waters began with the ANZAM agreement in 1948, but actual missions against the communist insurgents only commenced after the establishment of the FESR in 1955. Ever since, the RAN maintains a close relationship with its Malaysian counterpart. The directive of the FESR, as part of the forward defence strategy gave two roles for the RAN. Its primary role was to act as "a deterrent to further Communist aggression in South East Asia”, together with units of the Royal Navy. In an event of full scale war, it would have served in the defence of Malaya, Singapore and the sea lines of communication around those. Their secondary role was "to assist in the maintenance of the security of the Federation of Malaya by participating in operations against the Communist Terrorists.” On paper at least, these were the roles, but in practice, the secondary role was to dominate RAN operations in the late 1950's. [29]

As far as the command of RAN ships was concerned, the naval directive of FESR "transferred operational control of RAN ships deployed to the Far East Fleet to the Royal Naval Commander-in-Chief, Far East Station, and stressed the supremacy of the General Directive [of FESR—author].” [30] According to the naval directorate, RAN ships were deployed on 9 month long cruises, with the exception of Her Majesty's Australian Ship (HMAS) Melbourne, which only had 2 month long deployments at a time. [31: 57]

The first RAN units to arrive on station in Malayan waters were HMAS Arunta and Warramunga in June 1955, but their deployment was only 6 months long in the beginning. "They had been involved in exercising, patrolling the waters offshore of the Malayan Peninsula, and training with Malayan and Singaporean marine forces, but were not required to fire on enemy positions.” [32: 52] The role of naval forces in a counterinsurgency (COIN) war, especially when the enemy is hidden in the jungle, seems to be very limited, but RAN ships still played an important role, even when they were not firing their guns in anger.

First and foremost, "it should be noted that the effective naval blockade against the supply of arms and ammunition to the CTs from sources outside the country denied them any effective use of the sea throughout the Emergency." [29] Chin Peng stated that "We didn't receive any outside aid [...] not even a bullet", but this is an ambiguous statement and his forces did receive some supply from Singapore. [33: 192] Although there is no discovered evidence up to this date showing that a foreign power tried to resupply the MRLA, the deterring factor of the naval blockade must have played a part in that. The significance of this role comes to light especially when compared to the other major war in SEA, the Vietnam War. Complete naval blockade could not be established there, and insurgents in the South were resupplied from the North. Looking at the map of the Malayan Peninsula, it is also easy to see, that maintaining a complete naval blockade at such a long coastline was indeed a major achievement. Secondly, the strong naval presence, this traditional show of the flag was an important part of the British hearts and minds campaign aimed at strengthening Malayan 
resolve against the communists. [7: 29] Showing the flag was especially vital for the Malayan administration on the more remote, and less populated eastern part of the peninsula, which were far away from the central administration.

Altogether, the RAN deployed 13 warships on 35 tours of duties over the course of five years. For the sailors, "two tours were common, with three or four deployments by individuals by no means unusual, with some serving in more than one ship over the fiveyear period.” [30] As far as the number of service personnel is concerned, the naval contribution to Malaya "would amount to some 1,500 personnel annually [...] although the former figure included the 1,000 men for the regular visit of the carrier and it's embarked squadrons.” [29] The 13 ships were: HMAS ANZAC, Arunta, Melbourne, Quadrant, Queenborough, Quiberon, Quickmatch, Sydney, Tobruk, Vampire, Vendetta, Voyager, Warramunga. From these, Arunta and Warramunga were Tribal-class destroyers, Quadrant, Queenborough, Quiberon, and Quickmatch were Q-class destroyers, Tobruk and ANZAC Battle-class destroyers, and all were World War II veterans. [34: 6] The Q-class ships were serving with the RAN only since 1950, after that they were given as presents from the RN to the Menzies government. [35: 34] Newer designs were HMAS Vampire, Vendetta and Voyager of the Daring-class and these later saw service both in the Konfrontasi with Indonesia, and during the course of the war in Vietnam. [36]

HMAS Sydney, the Majestic-class light aircraft carrier, which served with distinction in the Korean War, never fired a shot in anger in Malaya, but visited ports in SEA as a projection of force and participated in SEATO exercises. She was decommissioned as an aircraft carrier in 1958, and her conversion to a troop carrier was finished only after the Emergency was over in 1962. [37] As with many RAN assets, she went on to play an important role for Australia in the Vietnam War. The other aircraft carrier and subsequent flagships of the RAN after her commissioning in 1956, HMAS Melbourne had a similar service as Sydney. The ship sailed in Malayan waters and participated in numerous SEATO exercises-including exercise Ocean Link, a huge undertaking with 24 ships and submarines from five nations participating-but she never fired a shot in anger. [38]

At the time of her deployment in Malayan waters, Melbourne possessed impressive capabilities. She had an angled flight-deck, steam catapult and mirror landing aid-built in. [39: 6] The De Havilland Sea Venom all-weather radar-equipped interceptors were the first of their kind in the Southern Hemisphere, and the Fairey Gannet anti-submarine-warfare aircraft could be used to maintain a naval blockade. However, her impressive capabilities were simply not required anymore, as the Emergency was winding down, and the land-based air assets were sufficient for the limited intensity conflict. The real offensive part played by the RAN in Malayan waters was Naval Gun Support (NGS), which took place on five occasions between 1956 and 1957, when RAN destroyers undertook such actions. As long as CT elements were operating close to the coast, naval bombardment was an effective and, more or less, stealthy way of disrupting them. [33: 194]

According to Pfennigwerth, the RAN, although participated in the fighting, it did not learn much from these operations. He states that "despite the demonstrated utility of inshore patrol craft during the Emergency, the RAN procured none that could be deployed either to Confrontation or to Vietnam when this kind of contribution was called for.” [33: 195] This was indeed backward thinking, since, for example, the United States learnt from the lessons of the French in Indochina in brown water naval operations and procured small crafts that 
were suited for such missions. Pfenningwerth explains this by writing "that RAN eyes were on the main game-defence of Southeast Asian sea lines of communication-rather than on the naval sideshow that anti-CT operations in Malaya were.” [33: 195] This indeed sounds like a possible explanation, since RAN did gain experience in other ways, but not in riverine warfare.

The role of RAN did not end in Malaya with the declaration of Malayan Prime Minister Tunku Abdul Rahman on the $31^{\text {st }}$ of July 1960. The RAN helped in the establishment of the Royal Malayan Navy, still stationed ships in the country as part of FESR, and even trained Malayan reserve units. For example, right after the end of the Emergency, HMA Ships Quiberon and Vendetta were both training Royal Malayan Naval Reserve cadets, while also showing the flag and visiting Malayan ports. Furthermore, RAN provided many officers for the new navy until Malayan officers were trained in sufficient numbers. [40: 32]

In the end, the RAN did not lose one single person due to enemy action, only 4 sailors lost their lives in accidents, and 43 others got injured, while the ships were in Malayan waters. Altogether, the Australian services suffered 15 killed in operation, and 27 wounded. The nonoperational casualties were higher, with 36 fatalities, and 172 wounded. Approximately 7,000 Australian servicemen served in Malaya from all services. [27]

\section{Conclusion}

The Australian experience in Malaya was a fairly successful one. It was the first limited armed conflict the nation took part in since the Boer War, and also the first time when Australia participated in a war on its own. Considering the number of servicemen, it suffered relatively low casualties, while also gained invaluable experience in new warfare methods, something that was to come handy in the next decades. COIN experts consider Malaya a model of a successful COIN war, something that is indeed very rare in the course of history. It is also regularly contrasted with the Vietnam War, firstly because of the many similarities, and secondly, because of the difference in British effort compared to the American one. The United Kingdom indeed spent significantly less resources and still won the struggle, but as it is illustrated on these pages, it only managed to do so with the help of Australian, and also New Zealand forces, which also contributed to the FESR, but their effort is not analysed here. Finally, Australian participation in the Malayan Emergency is also interesting to analyse as it came at a time, when Australian foreign policy experienced its greatest shift, something that is still influencing Australian policy decision.

\section{References}

[1] BODA J., BOLDIZSÁR G., KOVÁCS L., OROSZ Z., PADÁNYI J., RESPERGER I., SZENES Z:: Fókusz és együttmúködés. A hadtudomány kutatási feladatai. Honvédségi Szemle, 3 (2006), 3-19.

[2] PAUL, E. C.: Little America: Australia, the $51^{\text {st }}$ state. London: Pluto Press, 2006.

[3] ALCORN, R. F.: Australian Foreign Policy: WWII and Post War. Defence Force Journal, 63 (1987), 39-44. 
[4] The History of the Radford-Collins Agreement. Sea Power Centre-Australia, Nov (2007).

[5] STOCKWELL, A. J.: Malaya: Part II., The Alliance Route to Independence 1953-1957. British Documents on the End of Empire. London: HMSO, 1995.

[6] WOOD, S. P.: 60 Years Australia in Malaysia 1955-2015. Canberra: Australian Government, Department of Foreign Affairs and Trade, 2015.

[7] PFENNIGWERTH, I.: The Royal Australian Navy in Malaya, Malaysia and Singapore, 1948-1971. United Service, 59 (2008), 28-32.

[8] BROWN, A.: The history of the Radford-Collins Agreement. Navy, Serving Australia with Pride. www.navy.gov.au/history/feature-histories/history-radford-collins-agreement (Downloaded: 20.12.2017)

[9] The ANZUS Alliance. Defense Institute of Security Cooperation Studies, 4 (1987).

[10] Treaty of Friendship, Co-Operation and Mutual Assistance. Warsaw: United Nations Treaty Collection, 1955. https://reaties.un.org/doc/Publication/UNTS/Volume 219/volume-219I-2962-Other.pdf (Downloaded: 10.12.2017)

[11] Winston Churchill and the Cold War. Fulton: National Churchill Museum. s.d. www.nationalchurchillmuseum.org/winston-churchill-and-the-cold-war.html (Downloaded: 15.12.2017)

[12] SHORT, A.: The Communist Insurrection in Malaya 1948-1960. London: Frederick Muller Ltd., 1975.

[13] NAGL, J. A.: Counterinsurgency Lessons from Malaya and Vietnam: Learning to Eat Soup with a Knife. Santa Barbara: Praeger, 2002.

[14] TOMOLYA J., PADÁNYI J.: A terrorizmus és a gerilla-hadviselés azonosságai és különbségei. Hadtudomány, XXIV 1 Elektronikus szám (2014), 126-154.

[15] POSTGATE, M.: Operation Firedog: Air Support in the Malayan Emergency, 1948-1960. London: HMSO, 1992.

[16] PITTAWAY, N.: RAAF in the 1950s. Wings of Fame, 20 (2000), 140-157.

[17] BROOKE, F. H.: Infantry and Air Power in Malaya. Australian Army Journal, 64 (1954), 15-17.

[18] GARBETT, M., GOULDING, B.: Lincoln at War: 1944-1966. Shepperton: Ian Allan Publishing, 2001.

[19] EDWARDS, P.: Public Enemy Number One. Wartime: Official magazine of the Australian War Memorial, Aug (1999), 50-52.

[20] JACKSON, R.: The Malayan Emergency \& Indonesian Confrontation: The Commonwealth's War 1948-1966. Barnsley: Pen \& Sword, 2008.

[21] FARQUHAR, R.: The Avon Sabre. ADF-SERIALS Australian \& New Zealand Military Aircraft Serials \& History. www.adf-serials.com.au (Downloaded: 18.12.2017)

[22] HUGONNET, P.: Malayan Emergency. Voluntary Guides Backgrounder, 3 (2013).

[23] LEE, D.: Australia Turns to the United States 1955-1957. London: Sir Robert Menzies Centre for Australian Studies, 1993.

[24] Authority of the House of Representatives. Senate Official Hansard, No. 38, Commonwealth of Australia, 1955.

[25] GREY, J.: A Military History of Australia. Cambridge: Cambridge University Press, 2008.

[26] GARLAND, R. S.: Operations in Malaya. Australian Army Journal, 119 (1959), 25-31. 
[27] Australian Involvement and Casualties. Anzac Day Commemoration Committee. anzacday.org.au/malayan-emergency-australian-involvement-and-casualties

(Downloaded: 28.12.2017)

[28] Malaya. 1RAR The First Battalion Association. www.1rar.org.au/malaya-1959-1961/

(Downloaded: 20.12.2017)

[29] PERRYMAN, J.: The RAN, the Strategic Reserve and the Malayan Emergency. Navy, Serving Australia with Pride. www.navy.gov.au/history/feature-histories/ran-strategicreserve-and-malayan-emergency (Downloaded: 18.12.2017)

[30] RAN Service in the Far East Strategic Reserve During the Malayan Emergency 1955-1960. FESR (Australia), 2008.

[31] PFENNIGWERTH, I.: Tiger Territory: The Untold Story of the Royal Australian Navy in Southeast Asia from 1948 to 1971. Sydney: Rosenberg Publishing, 2008.

[32] YOUNG, K., RHETT, M.: The Commonwealth Navies: 100 Years of Cooperation. Canberra: Sea Power Centre - Australia, 2012.

[33] PFENNIGWERTH, I.: Missing Pieces: The Intelligence Jigsaw and RAN Operations from 1939-71. Canberra: Sea Power Centre, Department of Defence, 2008.

[34] FRANCIS, J.: The State of the RAN. The Navy, November (1955).

[35] Destroyer Gift to Australia. The Navy, July (1950).

[36] HMAS Vendetta (II). Navy, Serving Australia with Pride. www.navy.gov.au/hmas-vendetta-ii (Downloaded: 28.12.2017)

[37] HMAS Sydney (III). Navy, Serving Australia with Pride. www.navy.gov.au/hmas-sydney-iii (Downloaded: 28.12.2017)

[38] HMAS Melbourne (II). Navy, Serving Australia with Pride. http://www.navy.gov.au/hmasmelbourne-ii (Downloaded: 28.12.2017)

[39] HOBBS, D.: HMAS Melbourne (II) - 25 Years On. The Navy, (2007), 5-10.

[40] RAN Trains Malayan Ratings. The Navy, August (1961). 